Ayurlog: National Journal of Research in Ayurved Science

\title{
A new dimension to the classification of Ayurvedokta hridya dravyas and their possible mode of action
}

Subhash D. Waghe*1, Sanjay P. Deshmukh ${ }^{2}$, Kavita Agrawal ${ }^{3}$, Pradnya P. Thakre ${ }^{4}$

1. HOD - Dept. of Roga Nidana \& Vikruti Vigyana, KDMG Ayurvedic College, Chalisgaon, Maharashtra.

2. HOD, Dept. Of Roga Nidan \& V.V., Rajiv Lochan Ayurved College, Durg (C.G.)Pin code 491221 Email-sanju.spd@gmail.com

3. HOD, Dept. Of - Samhita Siddhanta, Shri Dhanwantari Ayurveda College, Semari Chhata, Mathura (UP)-281401; E-Mail -kavita201@gmail.com, Mo.no. 9423145159

4. Dept. Of Shalya Tantra, Shri K.R. Pandav Ayurved College \& Hospital, Dighori, Nagpur-440024 E-mail - pradnyathakre21@gmail.com

*Corresponding author: E-mail - carenidan@ rediffmail.com (contact no. 7038000648)

\section{Abstract:}

The death due to ischemic heart disease increasing in Indian population at alarming rate and accounts for around $15-$ $20 \%$ of all deaths in India. Similarly obesity, atherosclerosis and hypertension is also on the alarming rise. The faulty dietary habit with high intake of oily, fatty, carbohydrate rich food is one of the major reason for hyperlipidemia, atherosclerosis, hypertension and coronary artery disease. Ayurveda have well established doctrine of dietary ethics and regimen. Ayurveda had described the various heart pleasant and heart beneficial (Hridya) food items such as vegetables, fruits, flowers and drugs. But, Ayurvedokta "Hridya" dravyas are not classified into specific categories in classical texts depending upon their mode of action. Hence, needs to be classified and their mode of action with respect to their beneficial effect on heart also needs to be established. As per Ayurveda, heart is also a seat of mind and acts as independent

brain to carry out certain immediate responses. In the result it is found that "Ayurvedokta "Hridya" dravyas can be broadly classified into Kapha-har Hridya dravyas and Kapha-kar Hridya dravyas. These Hridya dravyas exert their heart pleasing action by various ways. For e.g. Hridya flower exert action by its pleasing fragrance and mood elevation. Hridya fruits exert their action by taste and vagal stimulation. It is concluded that Kaphahar Hridya dravyas are having beneficial effect on heart and are useful in controlling obesity, atherosclerosis and hypertension and thereby preventing coronary artery disease. The Kapha-kar Hridya dravyas are rich in carbohydrates and beneficial in improving the nutritional status of the body.

\section{KEYWORDS}

"Hridya" dravyas, Lipid lowering Agents,

Platelet inhibitors, clot lytics 
MATERIAL \& METHOD.

Literary method of research is adopted for the present study. Critical and analytical study of Ayurvedic as well as modern literature pertaining to the subject is carried out to come to the logical result and conclusion.

\section{OBSERVATIONS}

- Kapha-hara (Kapha Alleviating)Hrudya Spices \& Mouth Freshners

- Ela [Elttaria cardamomum] is beneficial to the heart and it lowers the elevated Kapha [D. Ni. 2/45 \& S.Su. 38/23]

- Talish [Abies webiana] is beneficial to the heart. It arouses the appetite. It lowers the Kapha.[D. Ni. 2/54]

- Dhanyaka (Coriander) [Coriandrum sativum] is beneficial to the heart and it clears th channels in the body [D. Ni. 2/6 \& S.Su. 46 / 231]

- Jiraka [Cuminum cyminicum] is beneficial to the heart. It lowers the Kapha by its hot and pungent properties [D.Ni. 2/66 \& S.Su. 46/229]

- Hingu [Ferula aesfoetida] is beneficial to the heart. It lowers the Kapha by its hot and pungent properties [D.Ni. $2 / 37$ \& $\quad$ S.Su. 46/228].

- Hingupatri is beneficial to the heart. [D.Ni. 2/39]

- Lawanga [Syzezium aromaticum] is beneficial to the heart. [A.S.Su. $12 / 84]$

- Jatipatri [Myristica fragrance] is beneficial to the heart and lowers the Kapha by its hot and pungent properties. It also removes the bad odour from mouth. [A.S.Su. 12/84\& D.Ni. 3/32]

- Katfal [Myrica nagi] is beneficial to the heart. [A.S.Su. 12/84]

- Betel leaf is beneficial for the heart. [D.Ni. 6/151]

- Kankol (Long pepper) [Piper cubeba]- It is beneficial to the heart and lowers the Kapha by its hot and pungent properties. It also removes the bad odour from mouth. [A.S.Su. 12/84 \& D.Ni. 3/32]

\section{Kapha-hara Hrudya Vegetables}

All tikta varga (bitter class) vegetables are Kapha-hara.

- Patol (pointed Gourd) [Trichosanthes diocia] is beneficial to the heart. [A.S.Su. 7/120], It also brings down the elevated blood sugar [S.Su. 38/7, S.Su. 46/262263 ].

- Wartak (Brinjal) [Solanum melongena] is beneficial to the heart. [A.S.Su. 7/22]

- Green vegetables are beneficial to the heart. [A.S.Su. 6/156-160]

- Mulika [Raphanus sativus] - It is beneficial for heart [S.Su. 4/240]

- Sunnishanaka [Celosia argentea] - It lowers all elevated tridoshas and alleviates coughing and dyspnoea [S.Su. 46/262-263]

- Gojivha [Onosma bracteatum] - It alleviates coughing and dyspnoea [S.Su. 46/262-263]

- Changeri [Oxalis corniculta] - It alleviates coughing and dyspnoea [S.Su. 46/262-263]

- Kakamachi [Solanum nigrum] - It alleviates coughing and dyspnoea [S.Su. 46/262-263] 
- Mandukparni [Centella asiatica]It alleviates coughing and dyspnoea [S.Su. 46/262-263]

- Prapunnad [Cassia tora]- It alleviates coughing and dyspnoea [S.Su. 46/262-263]

- Koshataki [Lagenaria sceraria]- It is beneficial to the heart. It lowers the Kapha and elevated blood sugar.

- Rajkoshataki [Luffa actangulata] - It is beneficial to the heart. It lowers the Kapha and elevated blood sugar [S.Su. 46/262-263]

- Guduchi [Tinospora cardifolia] It is beneficial to the heart. It lowers the Kapha and elevated blood sugar [S.Su. 46/262-263]

- Karwellaka

[Momordica charantia] - It is beneficial to the heart. It lowers the Kapha and elevated blood sugar [S.Su. 38/7]

Kapha-kar Hridya Fala Shaka

Kushmanda (Pumpkin) [Benincosa hispida] is beneficial to the heart. [D.Ni. 1/184]

Kapha-har (Kapha Alleviating)Hrudya Food Products

- Godugdha [Cow milk] is beneficial to the heart. [D.Ni. 6/151]

- Takra [Buttermilk] is beneficial to the heart. [D.Ni. 6/151]

There is a link between better gut bacterial flora and mood. It helps in reliving the anxiety and thereby regulating the bowel. The calm mind allows the heart to function well.

- Madhu [Honey] is beneficial to the heart. [D.Ni. 6/151]

- Mung Yusha - Semisolid preparation of green gram is beneficial for the heart. It also lowers the elvated Kapha. It also acts as appetizer. [S.Su. 46/366]

- Patol Nimba Yusha - Semisolid preparation of pointed gourd and citrus is beneficial for the heart. It also lowers the elvated Kapha. It also acts as appetizer. [S.Su. 46/370]

Kapha-kar Hridya Bhakshya Padarthas (Kapha Aggrvating Food Products)

- Dadim Amlaka Yusha Semisolid preparation of pomogrenate and emblic is beneficial for the heart. It also lowers the elvated Kapha. It also acts as appetizer. [S.Su. 46/373]

- Vilepi - Semisolid is beneficial for the heart. [D.Ni. 6/151]

- Plum powder is beneficial to the heart. [D.Ni. 6/151]

- Puran Guda (Old jiggery ) is beneficial to the heart. [D.Ni. 6/151]

- Sour sweet pickle is beneficial for the heart. [D.Ni. 6/151]

- Ghrit Pachit Bhakshya [Food preparation mixed with Ghee] - It is beneficial for heart and offers strength and complexion. [S.Su. 46/405]

- Ghritapura [Food preparation mixed with Ghee and Milk] - It is beneficial for heart and aphodisiac and promotes muscles. [S.Su. 46/393]

- Kshir krit Bhakshya [Liquid food preparation mixed with Milk]- It is beneficial for heart and offers strength, aphrodisiac and promotes nutrition. [S.Su. 46/392]

- Sattak [Liquid food preparation made by adding curd] - It is beneficial for heart and promotes kapha. [S.Su. 46/397] 
- Fenak [ Foamy food preparation made by adding ghee] - It is most beneficial for heart and very light. [S.Su. 46/399]

\section{Kapha-har (Kapha Alleviating)Hrudya} Fruits

- Aamra (Mango) [Mangifera indica] is beneficial to the heart. [A.S.Su. 15/15]

- Naranga (Orange) [Citrus reticulate] is beneficial to the heart. [D.Ni. 5/16]

- Dadima (Pomogrenate) [Punica granatum] is beneficial to the heart. [A.S.Su. 7/171]

- Matulunga/ Beejpur [Citrus medica] is beneficial to the heart. [D.Ni. 5/19]

- Draksha (Grapes) [Vitis vinifera] is beneficial to the heart. [D. Ni. 5/50]

- Badar (Plum) mauritiana] is beneficial to heart. [A.S.Su. 15/15]

- Karamarda [Carissa carandas] is beneficial to the heart. [A.S.Su. $15 / 15]$

- Aamlakam [Emblica officianale] is beneficial to the heart. [A.S.Su. 12/45]

- Aaruk [Prynus persica] is beneficial to the heart. [D.Ni. 5/83]

- Amlawetas [Garcinia pedunculata] is beneficial to the heart. [A.S.Su. $15 / 15$ ]

Kapha-kar (Kapha Aggravting)Hrudya Fruits

Narikel (Wet Coconut)[Cocos nucifera] is beneficial to the heart, flushes the urinary bladder and promotes the strength and built of the body. [A.S.Su. 7/175 \& S.Su. 46/180]. The water inside the unripe coconut is pleasing and beneficial to the heart [B.P.].
Ripened Mango is beneficial to the heart and it promotes semen formation. [A.S.Su. 7/189]

Possible action - They promote nutrition and thereby act as heart beneficial but in excess quantity they may lead to hyperlipidemia and hyperglycemia.

\section{Hrudya Flowers}

- Warshiki [Jasminum] is beneficial to the heart. [D.Ni. 5/125]

- Wasanti [Jasminum] is beneficial to the heart. [D.Ni. 5/128]

- Champak [Michella champaka] is beneficial to the heart. [D.Ni. 5/132]

- Kunda [Jasminum pubeseens] is beneficial to the heart. [D.Ni. 5/138]

- Damana [Artemisia vulgaris] is beneficial to the heart. [D.Ni 3/64]

- Saptaparna [Alstonia scholaris] is beneficial to the heart. [D.Ni. 3/80]

- Atimuktam [Hiptage medablota] is beneficial to the heart. [D. Ni. 5/141]

- Ashoka [Saraca asoca] is beneficial to the heart. [D.Ni. 5/147]

Hrudya Meat \& Meat Preparations

- Krakar and Chakrak (Brahmany duck) meat is beneficial to the heart. [S.Su 46/63]

- Deer meat is beneficial to the heart. [S.Su 46/55]

- Meat soup is beneficial to the heart. [A.S.Su. $7 / 47$ \& S.Su. 46 / 359]

- Sour meat soup is beneficial to the heart. [A.S.Su. 7/49]

Kapha-har Hridya Madyas (Kapha Alleviating Alcoholic Drinks)

- Puran Madya [Old Alcohol] - It is beneficial to the heart. It lowers 
the Kapha, kills the worms and arouses the hunger. [S.Su. 46/193]

- Mardwik Madya [Wine prepared from grapes ] - It is beneficial to the heart. [A.S.Su.6/126]

- Kharjur Madya [Wine prepared from dates ] - It lowers the kapha and helps in reducing the weight. [S.Su. 46/174]

- Sura Madya - It is beneficial for the heart. It alleviates the coughing dyspnoea and rhinorrhoea [S.Su. 46/175-76]

- Sura-asava - It is beneficial for the heart. It lowers the Kapha and vata. It acts as diuretic [S.Su. 46/175-76]

- Madhwa-asava - It lowers the blood sugar, acts as fat lowering agent and reduces edema [S.Su. 46/188]

- Maireyaka Madya - It lowers the Kapha and fat. Also act wormicidal [S.Su. 46/189]

- Madhukpushpa Madya - It lowers the Kapha and aggravates the Pitta. Also acts as appetite stimulizer. [S.Su. 46/191]

- Shukta [Vinegar] prepared from sugarcane juice is beneficial to the heart. [A.S.Su. 6/151]

- Dhanyamla Wine is beneficial to the heart. [AS.Su. 6/151]

- Sauviraka Wine is beneficial to the heart. [AS.Su. 6/151]

- Wine is beneficial to the heart. [AS.Su. 6/151]

Kapha-kar Hridya Madyas (Kapha Aggravating Alcoholic Drinks)

- Prasanna Madya - It promotes the Kapha and muscles. Increases the urine [S.Su.46/177].

- Sharkar Madya [Wine prepared by adding sugar]- It is beneficial for the heart. [A.S.Su. 6/128]. It flushes the bladder [S.Su. 46/183]

- Ekshurasa-asava -It lowers the Pitta, promotes Kapha and offers strength [S.Su. 46/190]

- Tushodak Wine is beneficial to the heart. [AS.Su. 6/151]

- Waruni alcohol is beneficial to the heart. [AS.Su. 6/151]

Alcohol acts as mood elevator in proper dose and creates the pleasant sensation. The alcohol may express feelings, may mask feelings or avoid feelings. Alcoholic preparations in this class are nutritious as they are rich in calories necessary for energy.

\section{Kapha-kar Hridya Beverages}

- Sour juices is pleasant to the heart. [A.S.Su. 6/151]

- Sour sweet mixed Beverages are pleasant to the heart. [A.S.Su. 6/151]

- Beverages made from falsa and plum fruit are beneficial to the heart. [S.Su. 46/390]

- Gangambu [Distilled Water] is beneficial to the heart. [A.S.Su. 6/151]

\section{Kapha-har Hrudya Drugs}

- Adraka [Zingiber Officianale] is beneficial to the heart. It lowers the Kapha by its hot and pungent properties. It also relieves the abdominal pain. [S.Su. 46/227]

- Nagar (Ginger) [ Zingiber officianale] is beneficial to the heart. . It lowers the Kapha by its hot and pungent properties. It also relieves the abdominal pain. [A.S.Su. 12/53\&S.Su.38/23]

- Saindhav [Rock salt] is beneficial to the heart. [ S.Su. 46/314 \& D.Ni. $2 / 26]$ 
- Saurvachala Salt is beneficial to the heart. [A.S.Su. 12/32 \& S.Su. 46/317]

- Vid salt is beneficial to the heart. [S.Su. 46/316]

- Yawa Kshar (Barley alkali) [Patassi carbonas] is beneficial to the heart. [A.S.Su. 2/19]

- Kshar (Alkali) is beneficial to the heart. [A.S.Su. 12/38]

- Bruhati/Kantakari [Solanum nigrum] -It lowers the Kapha and useful in cough and dyspnoea by its hot, bitter and pungent properties. [D.Ni. 1/96]

\section{Kapha-kar Hrudya Drugs}

Sahastravirya [Asparagus] is beneficial to the heart. [D. Ni. 1/294]

The medicines of Vidaryadi class are beneficial to the heart. They are useful in treating pthisis, excessive coughing and stertorus breathing associated wit tuberculosis. They promote the bod nutrition. [A.S.Su. 16/4 \& S.Su. 38/4-5]. The Medicines in this class are :

- Vidari-gandha/Shalparni

[Desmodium gangeticum] - It lowers the edema and sugar.

- Vidari-kanda [Pueraria tuberosa] - It offers strength and aphrodiasiac. Lowers the Pitta.

- Vidari [Ipomoea digitata] - It offers strength and aphrodiasiac. It is diuretic.

- Vishvadewa/Nagbala [Grewia hirsuta] - It lowers the Kapha and Pitta.

- Shwadanshtra [Tribulus terrestris] - It offers strength and aphrodiasiac. It lowers sugar.

- Pruthakparni/Prushniparni [Uraria picta] - It relieves couhing and dyspnoa.
- Shatavari [Asparagus racemosus] - It is aphrodiasiac and rejuvenator and useful in tuberculosis.

- Sariva [Hemidesmus indicus] - It lowers the elevated blood sugar. It regulates the thirst.

- Krushnasariva [Hemidesmus indicus] - It lowers the elevated blood sugar. It regulates the thirst.

- Jivaka [Microstylis wallichi] - It raises the Kapha and semen. It is useful in tuberculosis.

- Rishabhaka [Microstylis muscifera] - It raises the Kapha and semen. It is useful in tuberculosis.

- Mahasaha/Mashparni [Teramnus labialis] - It raises the Kapha and semen. It is useful in fever.

- Kshudrasaha/Mudagaparni [Phaseolus trilobus] - It raises the Kapha and semen. It is useful in fever.

- Punarnawa [Boerhavia diffusa] It is useful in cough and bronchitis and chest pain.

- Eranda [Ricinus communis] - It is aphrodisiac.

- Hansapadi/Vishwagranthi

[Adiantum lunulatum] - It is useful in healing the wounds.

- Vrushikali/Bichhubuti/Kanali/K apa [Urtica diocia]

\section{DISCUSSION}

Possible mode of action of hrudya spices - Spices are beneficial to the heart by its hot and pungent properties which prevents the clotting and sluggishness of blood and ensures the smooth flow of blood. Also their fragrance is heart pleasing giving pleasant sensation. Flavour is produced primarily by odour, taste contributes the sensation of salt, sweet, sour, bitter and savory. 
Possible mode of action of hrudya vegetables - Green leafy vegetables are rich in Vitamin $\mathrm{C}$, iron and other essential nutrients and thereby acts as beneficial for heart. Pointed gourd and brinjal are low calorie vegetables. Though pumpkin has been mentioned as Kaphakara by the acharyas but here they mentioned it as Hrudya. The green leafy vegetables are rich in magnesium which is related with mood and helps in reducing anxiety. In a Nutri grade study an optimal intake of whole grains, vegetables, fruits, nuts, legumes, dairy, fish, red and processed meat, eggs, and Sugar Sweetened Beverages was associated with a $65 \%$ reduced risk of $\mathrm{CHD}$ and optimal consumption of vegetables, fruits, dairy, and fish was associated with a $40 \%$ stroke reduction. Reducing the consumption of the risk-increasing food groups red meat, processed meat, SSB, eggs and dairy relation to Heart Failure is preventive.

Possible mode of action of Hrudya fruits- All sour fruits are rich in vitamin C and antioxidants and thereby it may be protecting the heart tissue from oxidative damages. The antioxidant like resveratrol present in green and purple grapes is equally helpful in reducing the LDL cholesterol and reducing risk of clot formation. Mental memories of taste (for e.g. of lemon or orange or tamrind) makes the mouth salivating. Omega 3 fatty acids in the fruits alter the brain chemicals linked with mood, specially dopamine and serotonin. It brings down the anxiety level. In nutrigrade study, consumption of citrus fruits found to lower the risk of coronary artery disease.

Possible mode of action of hrudya flowers - All hrudya flowers emit a fragrance which stimulate the production of happy harmone endorphins which keeps the mood happy and relieves stress and thereby protects the heart. Physiologically inhalation of fragrance stimulates the emotional and taste centers in the brain. It also stimulates the area controlling heart rate, blood pressure and mental stress. Researches at university of Vienna and Berlin recently found that specific chemical in sandlewood oil can increase the brain's oxygen level as much as to $20 \%$. By acting on emotional center, it reduces the anxiety, depression, insomnia and lifts the mood. The olfactory bulbs are part of limbic system and directly connects with limbic structure that process emotion (amygdala) and learning (hippocampus). No other sensory system has this type of link with neural areas of emotion. There is a separate branch called "Aromatherapy" which deals with the treatment of diseases by using fragrance and different scents.

Possible mode of action of Hrudya Meats - Though all meats are not beneficial for heart owing to their high fat content, the meat soup prepared after removing the excess fat as suggested by acharya Sushruta may act as source of protein for the body and thereby helping to improve the cardiac forces contraction.

Possible mode of action of Kapha-har Alcoholic preparations - The various alcoholic drinks mentioned in Ayurveda are like red wine which contain beneficial antioxidants like flavonoides, which can prevent the risk of coronary artery disease. Polyphenol like antioxidants such as resveratrol in red wine may help in protecting the linings of blood vessels. Resveratrol may help in reducing the LDL cholesterol thus preventing the risk of clot formation. The resveratrol in red wine comes from the skin of grapes used to make wine. Alcohol is pungent, hot, appetite stimulant, nutritious, bitter, sour 
and spreads easily. It equally benefits the lean and the obese if used judiciously. It flushes the systems and lowers the increased Kapha and Vata. The old alcohol is beneficial. As per acharya Vagbhata, The new alcohol is acidic, heavy much rich in calories, hence not beneficial for heart. [A.S.Su. 6/115-117]

Possible mode of action of Kaphakar Hridya Drugs - They are beneficial to the heart by various ways. Drugs like Sahastravirya, Saptaparna, Ashoka, Vidari may act as cardiotonic whereas Kshar is beneficial by fragmenting the thrombus and thrombotic lesions.

\section{RESULT}

The Ayurvedokta "Hridya" dravyas can very well be classified into Kapha-har and Kapha-kar class. The Kapha-kar class promotes weight gain and Kapha-har class promotes weight loss. They can have different modern pharmacological mode o actions as discussed in discussion.

\section{CONCLUSION}

The Kapha-har Hridya dravyas are having beneficial effect on heart and are useful in controlling hyperlipidemia, obesity, atherosclerosis and hypertension and thereby preventing coronary artery disease. The Kapha-kar Hridya dravyas are rich in carbohydrates and beneficial in improving the nutritional status of the body.

\section{ABBREVIATIONS}

S.Su.- Sushrut Sutrasthan

K.N. - Kaidev Nighantu

D.Ni - Dhanwantari Nighantu

A.S.Su. - Ashtang Sangraha Sutrasthana

REFERENCES

1.'Sushrut Samhita' with
'Nibandhasangrah' commentary by
Dalhan published by Chaukhamba Surbharati, Gopal Mandir lane, Varanasi221001
2. 'Bhavprakash Samhita' by Bhav Mishra published by Chaukhamba Krishnadas Academy, Gopal Mandir lane, Varanasi-221001

3. 'Dravygun Vijnana' by J.L.N.Shastry, published by Chaukhamba Orientalia, Gopal Mandir lane,Varanasi-221001

4. 'Dhanwantari Nighantu' edited by Dr Zharkhande Oza and Dr. Umapati Mishra published by Chaukhamba Surbharati Publication, Gopal Mandir lane, Varanasi221001

5. 'Raj Nighantu' edited by Dr. Indradeva Tripathi published by Chaukhamba Krishnadas academy, Gopal Mandir lane,Varanasi-221001

6. 'Kaidev Nighantu' edited by Dr. Indradeva Tripathi published by Chaukhamba Krishnadas academy, Gopal Mandir lane,Varanasi-221001

7. Kaumudi J. Joshipura, ScD; Alberto scherio, MD; JoAnn E. Manson, MD; et Meir J. Stampfer, MD; Eric B. Rimm, ScD; Frank E. Speizer, MD; Charles H. Hennekens, MD; Donna Spiegelman, ScD; Walter C. Willett, MD, Fruit and Vegetable Intake in Relation to Risk of Ischemic

Stroke.

JAMA. 1999;282(13):1233-1239.

doi:10.1001/jama.282.13.1233

8. He, F. J., C. A. Nowson, M. Lucas, and G. A. MacGregor. 2007. Increased consumption of fruit and vegetables is related to a reduced risk of coronary heart disease: Meta-analysis of cohort studies. $J$ Hum

Hypertens 21:717-728. doi:10.1038/sj.jhh.1002212.

9. He, F. J., C. A. Nowson, and G. A. MacGregor. 2006. Fruit and vegetable consumption and stroke: Meta-analysis of cohort studies. Lancet 367:320-326. doi:10.1016/S0140-6736(06)68069

10.

Gan, Y., X. Tong, L. Li, S. Cao, X. Yin, C. 
Gao, C. Herath, W. Li, Z. Jin, Y. Chen,an d Z. Lu. 2015. Consumption of fruit and vegetable and risk of coronary heart disease: A meta-analysis of prospective cohort studies. Int J Cardiol 183 : 129137. doi:10.1016/ j.ijcard. 2015. 01. 077.

11. Bhupathiraju, S. N., N. M. Wedick, A. Pan, J. $\quad$ E. Manson, K. M. Rexrode, W. C. Willett, E. B. Rimm, and F. B. Hu. 2013. Quantity and variety in fruit and vegetable intake and risk of coronary heart disease. Am $J$ Clin Nutr 98:1514-23.

doi:10.3945/ajcn.113.066381.

12. Rautiainen, S., E. B. Levitan, M. A. Mittleman, and A. Wolk. 2015. Fruit and vegetable intake and rate of heart failure: a population-based prospective cohort of women. Eur J Heart Fail 17:2026. doi: 10.1002/ejhf.191.

13.Dauchet, L., J. Ferrieres, D. Arveiler, J. W. Yarnell, F. Gey, P. Ducimetiere, J.B. R uidavets, B. Haas,A. Evans, A. Bingham, P. Amouyel,

and J. Dallongeville. 2004. Frequency of fruit and vegetable consumption and coronary heart disease in France and Northern Ireland: the PRIME study. $\mathrm{Br} J$ Nutr 92:963-972. doi:10.1079/BJN20041286.

14. Dauchet, L., P. Amouyel, S. Hercberg, and J. Dallongeville. 2006. Fruit and vegetable consumption and risk of coronary heart disease: A meta-analysis of cohort studies. J Nutr136:2588-93

Cite article:

A new dimension to the classification of Ayurvedokta hridya dravyas and their possible mode of action

Subhash D. Waghe, Sanjay P. Deshmukh, Kavita Agrawal, Pradnya P. Thakre Ayurlog: National Journal of Research in Ayurved Science- 2019; (7)(1): 1-9 